\title{
Effects of shear stress on the microalgae Chaetoceros muelleri
}

\author{
Michiel H. A. Michels • Atze J. van der Goot • \\ Niels-Henrik Norsker · René H. Wijffels
}

Received: 20 January 2010/Accepted: 12 February 2010/Published online: 27 February 2010

(C) The Author(s) 2010. This article is published with open access at Springerlink.com

\begin{abstract}
The effect of shear stress on the viability of Chaetoceros muelleri was studied using a combination of a rheometer and dedicated shearing devices. Different levels of shear stress were applied by varying the shear rates and the medium viscosities. It was possible to quantify the effect of shear stress over a wide range, whilst preserving laminar flow conditions through the use of a thickening agent. The threshold value at which the viability of algae was negatively influenced was between 1 and $1.3 \mathrm{~Pa}$. Beyond the threshold value the viability decreased suddenly to values between 52 and $66 \%$. The effect of shear stress was almost time independent compared to normal microalgae cultivation times. The main shear stress effect was obtained within $1 \mathrm{~min}$, with a secondary effect of up to 8 min.
\end{abstract}

Keywords Microalgae - Chaetoceros muelleri . Shear stress · Viability · Aquaculture feed · Photobioreactor design

M. H. A. Michels $(\bowtie) \cdot$ N.-H. Norsker · R. H. Wijffels Bioprocess Engineering, Wageningen University, P.O. Box 8129, 6700 EV Wageningen, The Netherlands e-mail: michiel.michels@wur.nl

M. H. A. Michels

HZ University of Applied Sciences, P.O. Box 364, 4380 AJ Vlissingen, The Netherlands

A. J. van der Goot

Laboratory of Food Process Engineering, Wageningen

University, Wageningen, The Netherlands

\section{Introduction}

Microalgae are cultivated to serve as feed for aquaculture (shellfish, shrimps and fish), animal feed (pets and farming), human nutrition, cosmetics and the production of high-value ingredients, such as polyunsaturated fatty acids and pigments [1]. The current market size of microalgal biomass is about 5,000 $\mathrm{t}$ dry matter/year of which at least $1,000 \mathrm{t}$ dry matter/year is produced for aquaculture [2, 3].

We are interested in the production of microalgae as a feed for bivalves. In general, cultivation of microalgae for these applications takes place in transparent plastic bags. Because the capacity of these systems is relatively small, labor cost per amount of feed for bivalve production is high. This explains why alternative large scale production systems for microalgae are being investigated. Such systems can consist of open ponds, bubble columns, flat-plate photobioreactors (PBRs) and tubular PBRs [4-6]. PBRs seem to be most promising in cultivating these microalgae on a large scale, because of low contamination risk, low space requirement, almost no $\mathrm{CO}_{2}$ loss, high adaptability to many species and high biomass concentration [7, 8]. However, it is suspected that the large hydrodynamic forces present in the PBR could cause shear stress levels that might be too severe for the sensitive microalgae, which would lead to reduced growth or even cell death [9]. Nevertheless, a high mixing intensity is necessary to keep microalgae in suspension, to achieve a sufficient light distribution and to enhance mass transfer. For the optimal design of PBRs, it is therefore important to know the maximum level of shear stress that can be tolerated by the microalgae.

Damage because of shear stress has been demonstrated both in bubble columns due to gas sparging [10-14] and in tubular PBRs due to pumping action $[12,15,16]$. Although 
cases of shear damage were described, shear stress was only quantified indirectly by using the liquid flow rate or the number and frequency of pump passages. A first step towards quantification of the shear rate or shear stress was done by Contreras et al. [17] and García Camacho et al. [18]. They used the energy dissipation to calculate an average shear rate or shear stress. For Phaeodactylum tricornutum, a shear rate value of $7,000 \mathrm{~s}^{-1}$ led to the highest growth rate caused by a balance between mass transfer limitations and shear damage [17]. Sensitivity to shear stress is dependent on the microalgae species used. This has been shown in a study with the dinoflagellate Protoceratium reticulatum, where a damage threshold was observed already at an average shear stress of $0.16 \mathrm{mPa}$, which was equivalent to a shear rate of $0.12 \mathrm{~s}^{-1}$ [18].

In order to apply a well-defined shear stress, Couette devices have been used in several studies. Couette devices consist of coaxial cylinders, where either the inner cylinder rotates and the outer remains stationary or vice versa. The effect of shear stress on photosynthesis of Spirulina platensis has been studied using a Couette device [19]. It was found that the oxygen production rate and the chain length of Spirulina platensis started to decrease when the shear stress exceeded 0.3 Pa. Experiments on cyanobacteria [20] indicated that a shear rate of as little as $2.2 \mathrm{~s}^{-1}$ reduced nitrogenase activity and $\mathrm{CO}_{2}$ fixation. However, the applied shear stress levels were not given, because the shear viscosity was not measured. Couette shearing devices have also been used to study the effect of shear stress on bioluminescence of different dinoflagellate species [21-24]. Bioluminescence threshold values were to the order of $0.1-1 \mathrm{~Pa}$, where the shear stress was calculated as a function of the shear rate and the viscosity of the medium. Shear stress thus appears to trigger bioluminescence in these cases, but the relationship to cell damage or viability is unclear.

The aim of this study is to determine the shear sensitivity of Chaetoceros muelleri. In addition, the time scale in which the effects of shear stress take place will be examined. The purpose was to understand whether the adverse effects were caused by a prolonged exposure to excessive shear stress or if the algal cells were damaged instantaneously. The combination of shear cylinders as Couette devices and rheological measurements was used in order to study the effect of a uniform and well-defined shear stress on the viability of Chaetoceros muelleri.

\section{Materials and methods}

Culture preparation

The diatom Chaetoceros muelleri (CCMP 1316) was obtained from NIOO (Netherlands Institute of Ecology,
Yerseke, The Netherlands). Chaetoceros muelleri was cultivated in natural seawater from the Easterscheldt (location Yerseke) enriched with Walne medium modified from Laing [25]. The salinity of the seawater used was $32 \mathrm{~g} \mathrm{~L}^{-1}$.

Cultures of Chaetoceros muelleri were maintained in $10 \mathrm{~mL}$ test tubes, $250 \mathrm{~mL}$ Erlenmeyer flasks containing $100 \mathrm{~mL}$ medium and $3 \mathrm{~L}$ Erlenmeyer flasks containing $2 \mathrm{~L}$ medium at $20{ }^{\circ} \mathrm{C}$. Light was supplied continuously by white fluorescent light. Every week $10 \%$ of the culture was transferred to new medium.

All shear stress experiments were carried out with batch cultures from the $3 \mathrm{~L}$ Erlenmeyer flasks after 1 week of growth, at which point the algae were in the early stationary phase. Locust bean gum (LBG) was applied as a thickener to increase the medium viscosity. In the rest of this article, the term medium refers to the enriched seawater including the thickener. The thickener was used in the following concentrations: $0,0.3$ and $0.5 \%$. Cell concentrations in the experiments varied between 5 and 10 million per $\mathrm{mL}$. The cell concentrations in the LBG solutions were $50 \%$ of the original culture, because $50 \mathrm{~mL}$ of the original culture was mixed with $50 \mathrm{~mL}$ of 0.6 or $1.0 \%$ LBG solution.

Shearing the algae

The effect of shear stress on the viability of Chaetoceros muelleri was studied, using four shear cylinders developed at the Laboratory of Food Process Engineering. The shear cylinders have the following dimensions: an inner cylinder with a length of $145.5 \mathrm{~mm}$ and a radius of $20 \mathrm{~mm}$ and an outer cylinder with a radius of $21 \mathrm{~mm}$. Between the inner and the outer cylinder is a gap of $1 \mathrm{~mm}$. The total volume between the cylinders is $20 \mathrm{~mL}$. The inner cylinder rotates and the outer cylinder is stationary. The shear rate applied in the shear cylinders is proportional to the rotational speed; the conversion factor of rotational speed (rpm) to shear rate $\left(\mathrm{s}^{-1}\right)$ is 2.157 . The maximum shear rate of the shear cylinders is $1,079 \mathrm{~s}^{-1}$ obtained at a rotational speed of $500 \mathrm{rpm}$. The shear rate is given as:

$\dot{\gamma}=\frac{2 R_{\mathrm{o}} R_{\mathrm{i}} \omega}{R_{\mathrm{o}}^{2}-R_{\mathrm{i}}^{2}}$

where $\dot{\gamma}$ is the shear rate $\left(\mathrm{s}^{-1}\right), \omega$ is the angular velocity of the outer cylinder $\left(\mathrm{s}^{-1}\right), R_{\mathrm{o}}$ is the outer cylinder inner radius $(\mathrm{m})$ and $R_{\mathrm{i}}$ is the inner cylinder outside radius (m) with:

$\omega=\frac{2 \pi n}{60}$

where $n$ is the rotational speed (rpm) of the shear cylinder.

In the first experiment Chaetoceros muelleri without LBG was exposed to different levels of rotational speed, 
which were $0,4,20,100$ and $500 \mathrm{rpm}$, respectively. The levels of rotational speed applied to the algae in $0.3 \%$ LBG were $0,4,10,15,20,100$ and $500 \mathrm{rpm}$, respectively. The algae in $0.5 \%$ LBG were exposed to the following levels of rotational speed: $0,2,4,10,20$ and $100 \mathrm{rpm}$. The exposure time to the different levels of shear stress was $1 \mathrm{~h}$ and the temperature $4{ }^{\circ} \mathrm{C}$. All exposures in the shear cylinders were done in triplicate.

A second experiment was carried out to investigate the time dependence of shear stress effect. Algae in 0.3\% LBG were exposed to a rotational speed of $100 \mathrm{rpm}$ for different times of exposure ranging from 1 to $120 \mathrm{~min}$. The temperature was $4{ }^{\circ} \mathrm{C}$ as in the first experiment. All tests were done in triplicate.

For all treatments the Taylor number was calculated to find out whether flow instabilities occurred. Taylor vortices will be formed when the Taylor number is higher than the limiting value of 41.3 [26, 27]. The Taylor number is defined as:

$T a=\left\lfloor\omega \rho R_{\mathrm{i}}^{2}\left(\delta_{\mathrm{cc}}-1\right)^{3 / 2}\right\rfloor / \eta$

where $\omega$ is the angular velocity, $\rho$ is $1,024 \mathrm{~kg} \mathrm{~m}^{-3}$ for seawater with algae at $4{ }^{\circ} \mathrm{C}, \eta$ is the apparent viscosity (Pa s) and $\delta_{\mathrm{cc}}$ is the ratio of the outer to the inner cylinder radius, which is 1.05 .

\section{Rheological characterization}

The shear stress was measured with a sample of $3.6 \mathrm{~mL}$ of the algae (without LBG, in 0.3 and $0.5 \%$ LBG solution) after exposure in the shear cylinders. A rheometer (type Physica MCR 301, Anton Paar) was used to measure the exact shear stress applied in the shear cylinders. The measurements were done at $4{ }^{\circ} \mathrm{C}$.

From the shear stress, the apparent viscosity can be calculated using the following equation:

$\eta=\frac{\tau}{\dot{\gamma}}$

where $\tau$ is the shear stress $(\mathrm{Pa}), \eta$ is the apparent viscosity (Pa s) and $\dot{\gamma}$ is the shear rate $\left(\mathrm{s}^{-1}\right)$.

For Newtonian fluids, $\eta$ is independent of $\dot{\gamma}$ and for nonNewtonian fluids, $\eta$ depends on $\dot{\gamma}$ [26]. The power-law model was used to describe this dependence [28, 29].

$\eta=m|\dot{\gamma}|^{n-1}$

The parameters $m$ and $n$ were measured from a log-log plot with apparent viscosity against shear rate.

The same power-law model is used to measure the dependence between shear rate and shear stress [26].

$\tau=c \eta^{n}$

The parameters $c$ and $n$ were also measured from a $\log -\log$ plot of shear stress versus shear rate.
Assessment of the viability

The viability of the algae was measured by using the fluorescein diacetate (FDA) staining method. Esterases in viable cells cleave FDA with the formation of fluorescein as a result. Fluorescein is a compound that fluoresces green in viable cells and does not give fluorescence in non-viable cells $[30,31]$. A FDA stock solution was prepared by dissolving $46 \mathrm{mg}$ FDA (Sigma) in $10 \mathrm{~mL}$ acetone $(11 \mathrm{mM})$ and stored in the dark at $-4{ }^{\circ} \mathrm{C}$. One milliliter of the sample containing the algae was incubated with $10 \mu \mathrm{L}$ FDA stock solution for $20 \mathrm{~min}$ [32]. Then the total amount of algal cells and the viable cells were counted in a cell chamber (hemocytometer DHC-B02-5 Büker Türk) using a fluorescence microscope (Olympus IX71). Viability of the algae was taken as the percentage of fluorescing algae.

In LBG, the algal cells did not settle at the bottom of the cell chamber, but were suspended over the $0.1 \mathrm{~mm}$ depth of the cell chamber. To count the cells, it was therefore necessary to scan over the depth of the cell chamber by adjusting the focus of the microscope.

\section{Results and discussion}

\section{Flow regime characterization}

Figure 1 shows the relation between the shear rate and shear stress applied to the algae suspension without LBG, in $0.3 \%$ LBG and in $0.5 \%$ LBG. As expected, higher shear stress levels could be obtained through an increase in either the shear rate or the viscosity, with the help of a thickener. LBG led to a shear-thinning behavior. The slopes of the flow curves with shear stress as a function of shear rate on a logarithmic scale are less steep for the LBG concentrations. This can also be seen in the power-law model functions where $n<1$ for the algae in LBG, while $n \approx 1$ for the algae without LBG (Eq. 6).

The shear stress levels that were applied in the further experiments were calculated with the power-law model functions in Fig. 1 and are presented in Table 1.

Viscosity as a function of shear rate is shown in Fig. 2 for the algae without LBG, the algae in $0.3 \%$ LBG and $0.5 \%$ LBG, respectively. The viscosity of the algae without LBG, which is the original culture of Chaetoceros muelleri in the medium, is almost independent of the shear rate. Therefore, the algae without LBG behave nearly Newtonian. This Newtonian behavior suggests that there is little interaction between the algal cells in the suspension and that they behave as separate cells, rather than as clustered cells.

Non-Newtonian behavior is apparent for the algae in LBG, where shear-thinning is evident. Therefore, the 


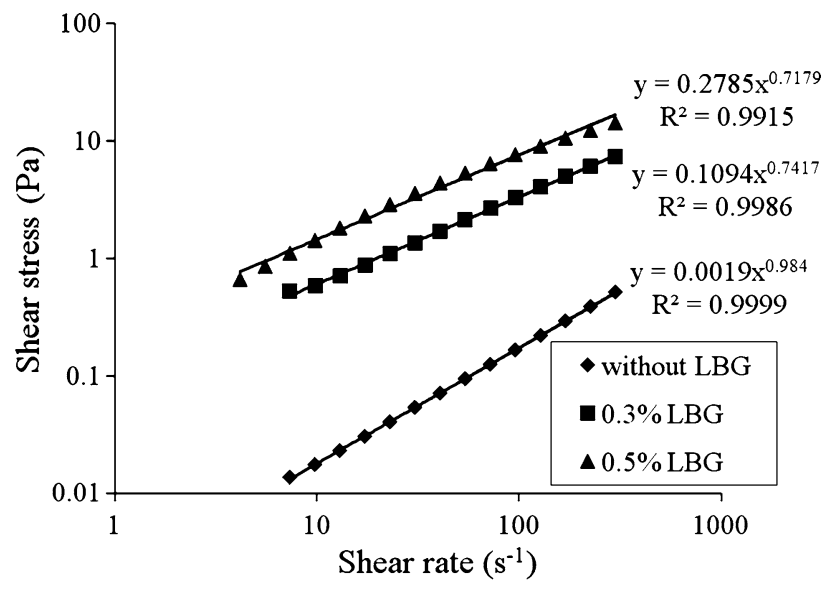

Fig. 1 Shear stress as a function of shear rate: algae without LBG (diamonds), algae in $0.3 \%$ LBG (squares) and algae in $0.5 \%$ LBG (triangles)

apparent viscosity needs to be determined at the different shear rates for the calculation of the accurate shear stress levels applied. A study of shearing insect cells has also indicated that assuming Newtonian behavior of cell cultures could cause substantial error in shear stress estimates [29].

The Taylor number for every apparent viscosity value was calculated with Eq. 3 (Table 1). In all experiments laminar flow was maintained, except at the highest shear rate of $1,079 \mathrm{~s}^{-1}$ in the algae dispersion without LBG. Taylor vortices may have been formed during that experiment and this could have led to secondary flow to a certain extent. The highest shear rate that can be applied for algae without LBG, while keeping the algae in laminar flow, is about $150 \mathrm{~s}^{-1}$. The use of LBG increased the viscosity, leading to a lower Taylor number. For that reason, LBG or other thickeners can be used to reach higher shear stress under stable laminar flow to the extent that they do not affect the viability directly. Maldonado and Latz [24] also used thickeners to increase the viscosity for applying two different shear stress levels at the same shear rate to study the short-term effect of shear stress on a dinoflagellate.

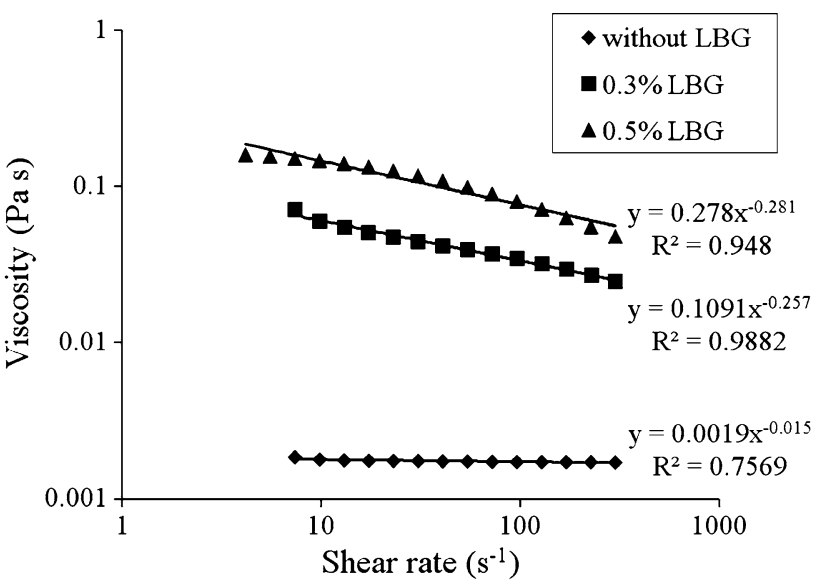

Fig. 2 Viscosity as a function of shear rate: algae without LBG (diamonds), algae in $0.3 \%$ LBG (squares) and algae in $0.5 \%$ LBG (triangles)

The dimensions of the shear cylinders are also important in creating a stable laminar flow, because the diameter of the inner cylinder and the gap between the inner and outer cylinder are relatively small. A Couette device with a bigger inner cylinder diameter and a relatively bigger gap leads to a smaller critical angular velocity with the formation of Taylor vortices or turbulent flow as a result $[33,34]$. It is difficult to determine the applied shear stress if flow instabilities are present.

The effect of shearing treatment on viability

In all processing conditions tested, the shape of the cells was unaltered. This holds for the viable cells as well as for the non-viable cells. The total cell concentration of the algae that were exposed to the high shear stresses did not decrease either. The viable and non-viable cells could only be discriminated by the FDA staining method, where the viable cells showed fluorescence (Fig. 3). Obviously, the affected cells must be damaged internally without any visible external impact observed in quiescent conditions after the shearing treatment.

Table 1 Shear stresses applied and Taylor numbers in relation with shear rates

\begin{tabular}{llllllll}
\hline $\begin{array}{l}\text { Rotational } \\
\text { speed }(\mathrm{rpm})\end{array}$ & $\begin{array}{l}\text { Shear rate } \\
\left(\mathrm{s}^{-1}\right)\end{array}$ & $\begin{array}{l}\text { Shear stress without } \\
\text { LBG }(\mathrm{Pa})\end{array}$ & $\begin{array}{l}\text { Taylor number } \\
\text { 0\% LBG }\end{array}$ & $\begin{array}{l}\text { Shear stress } 0.3 \% \\
\text { LBG }(\mathrm{Pa})\end{array}$ & $\begin{array}{l}\text { Taylor number } \\
0.3 \% \text { LBG }\end{array}$ & $\begin{array}{l}\text { Shear stress } 0.5 \% \\
\text { LBG }(\mathrm{Pa})\end{array}$ & $\begin{array}{l}\text { Taylor number } \\
0.5 \% \text { LBG }\end{array}$ \\
\hline 0 & 0 & 0 & 0 & 0 & 0 & 0 & 0 \\
2 & 4.31 & - & - & - & - & 0.795 & 0.0052 \\
4 & 8.63 & 0.016 & 1.04 & 0.541 & 0.031 & 1.31 & 0.013 \\
10 & 21.57 & - & - & 1.07 & 0.097 & 2.53 & 0.041 \\
15 & 32.36 & - & - & 1.44 & 0.162 & - & - \\
20 & 43.14 & 0.077 & 5.39 & 1.78 & 0.232 & 4.15 & 0.100 \\
100 & 215.7 & 0.376 & 27.6 & 5.89 & 1.76 & 13.2 & 0.783 \\
500 & 1,079 & 1.83 & 141 & 19.4 & 13.3 & - & - \\
\hline
\end{tabular}


The effect of shear rate on the viability is shown in Fig. 4. Without LBG, no effect of shear rate on the viability of the algae was observed. No effect on the viability of the algae in $0.3 \%$ LBG was seen until a shear rate of $22 \mathrm{~s}^{-1}$. Higher shear rates applied to the algae in $0.3 \%$ LBG affected the algae negatively, reducing the viability to $56 \%$. At a shear rate of $8.6 \mathrm{~s}^{-1}$ applied to the algae in $0.5 \%$ LBG, the viability dropped to a value of $59 \%$. Increasing the shear rate reduced the percentage of viable cells slightly to $52 \%$. There seems to be a slight difference between the viability levels of the samples with 0.3 and $0.5 \%$ LBG. We believe that these differences might be attributed to the fact that the experiments were done on different days. In addition, LBG did not affect the viability of the algae directly. No negative effect on the viability was seen when the algae in 0.3 and $0.5 \%$ LBG were not sheared. Furthermore, $100 \%$ viability was seen when low shear rates were applied to the algae in both LBG concentrations.

From Fig. 4, it can be seen that the shear rate is not the determining factor in explaining the negative effect on cell viability. Obviously, a higher viscosity leads to a lower shear rate at which a negative effect can be observed. When analyzing the effect of shear stress on the viability, the effects of shear rate and viscosity can be combined. The effect of all different levels of shear stress on the viability of Chaetoceros muelleri can be seen in Fig. 5.

Shear stress values up to $1 \mathrm{~Pa}$ had no effect on the viability. At shear stress levels higher than $1.3 \mathrm{~Pa}$, a sharp drop in viability can be seen with resulting viabilities between 52 and $66 \%$. The threshold value of shear stress for Chaetoceros muelleri is therefore to be found between 1 and $1.3 \mathrm{~Pa}$. A further increase of the shear stress to $19.4 \mathrm{~Pa}$ did not reduce the viability significantly. The effect of shear stress on the viability of Chaetoceros muelleri can thus be described as a step response with an almost similar effect beyond the threshold value, which is represented by the dotted line in Fig. 5. This would suggest that only a certain percentage of the cells are sensitive to shear stress

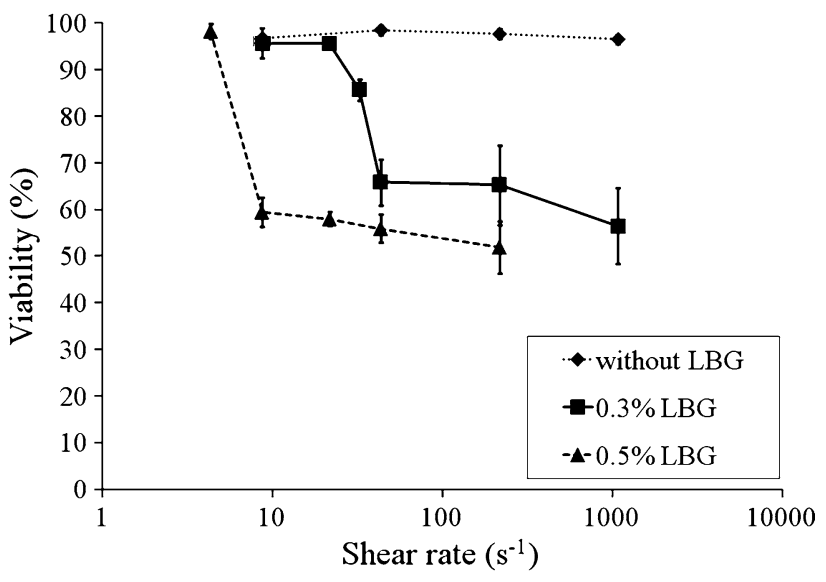

Fig. 4 Effect of shear rate on the viability of Chaetoceros muelleri; without LBG (diamonds), 0.3\% LBG (squares) and 0.5\% LBG (triangles). Error bars represent $95 \%$ confidence intervals

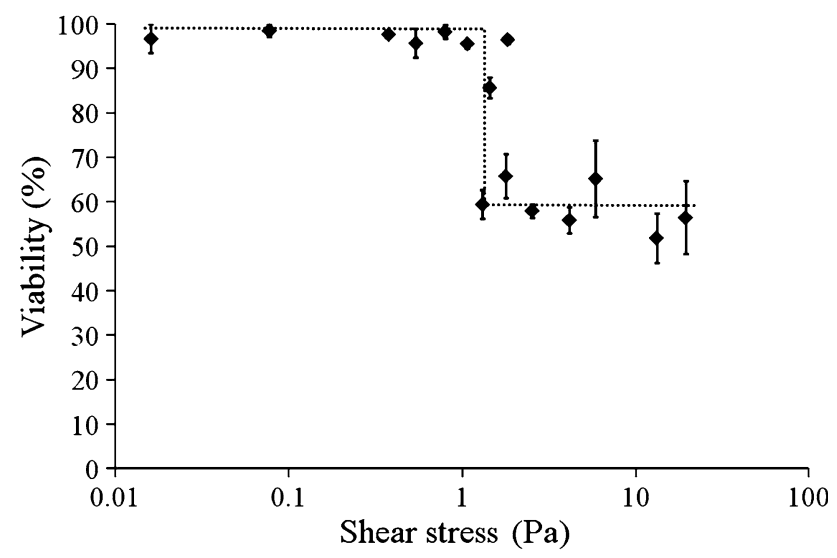

Fig. 5 Effect of shear stress on the viability of Chaetoceros muelleri with all treatments (without LBG, $0.3 \%$ LBG and $0.5 \%$ LBG) taken together. Error bars represent $95 \%$ confidence intervals

and that higher shear stresses than the threshold value, up to the maximum applied value of $19.4 \mathrm{~Pa}$, only affect the sensitive cells. Although it is unclear which cells are more susceptible to shear stress, other studies have speculated that shear stress disrupts cell division [18, 35]. Dividing
Fig. 3 Microscopic pictures of Chaetoceros muelleri; with normal light (a) 11 cells can be counted and with fluorescent light (b) 8 viable cells show fluorescence
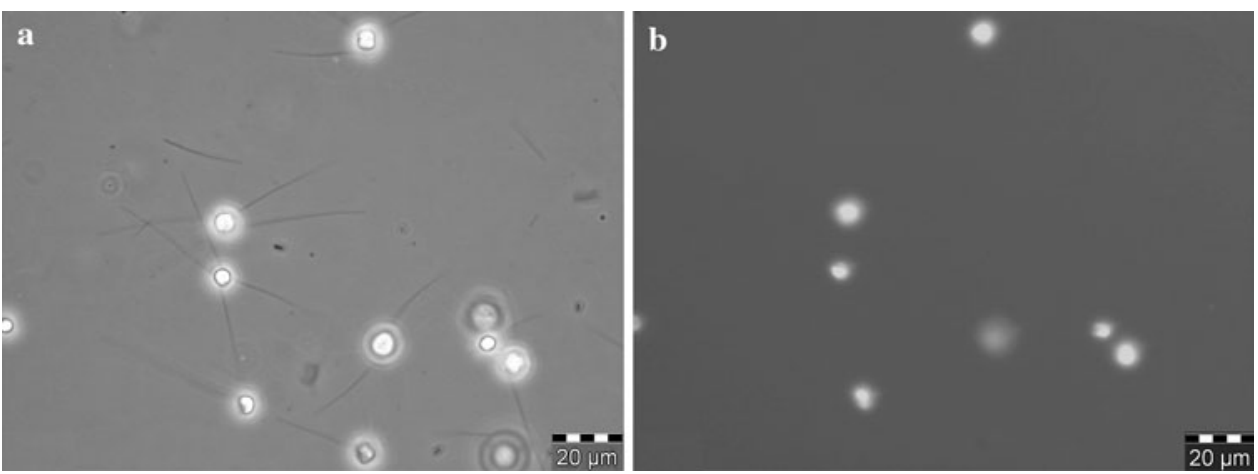
cells are probably more shear sensitive. Step responses to shear stress have previously been reported for enzymes [36] and starch molecules [37, 38], suggesting a more general role of shear stress in deactivation and breakage processes.

The only deviation from the general interpretation of our results is that a shear stress of $1.8 \mathrm{~Pa}$ could be applied to the algae without LBG at the highest shear rate without any detrimental effect on the viability. Flow instabilities like Taylor vortices could have occurred in that experiment, so that the results could have been influenced in a way that they are not reliable or comparable.

These results imply that a PBR for cultivating Chaetoceros muelleri should be designed in such a way that the maximum exhibited shear stress is lower than the threshold value. The question that now remains is whether this shear stress can occur in a PBR. Considering the study of Contreras et al. [17], shear rates up to $14,000 \mathrm{~s}^{-1}$ can occur, which implies a local shear stress of about $20 \mathrm{~Pa}$. This value clearly exceeds the value reported above. In other words, shear stress is likely to negatively influence the algae in a PBR. However, reducing the fluid velocity too much can lead to other limitations, such as mass transfer, which also negatively influences the growth rate.

Time dependence of shear stress effect

Chaetoceros muelleri in 0.3\% LBG was exposed to a constant shear stress of $5.89 \mathrm{~Pa}$ at a shear rate of $215.7 \mathrm{~s}^{-1}$ in the shear cylinders to elucidate the time dependence of the shear stress effects. The viability already decreased after $1 \mathrm{~min}$ to $82 \%$ and kept on decreasing at a reduced rate for the following $7 \mathrm{~min}$. Longer exposure times to

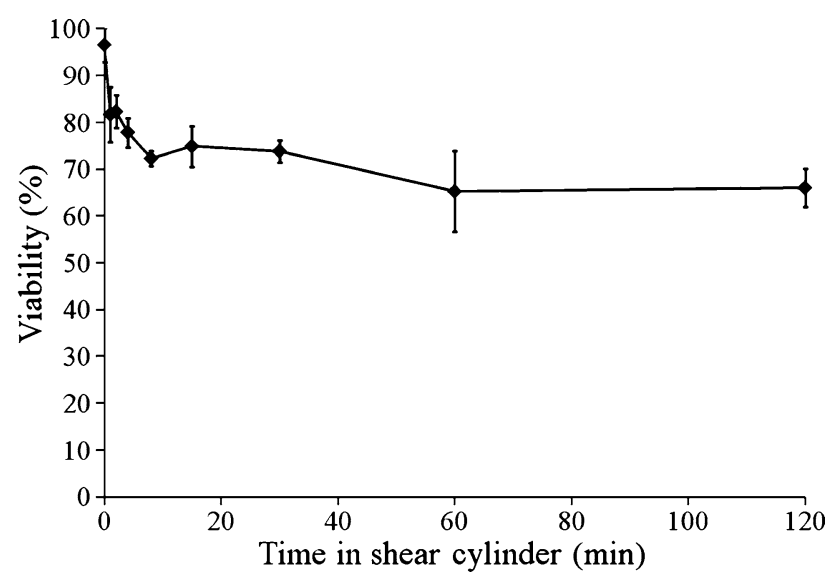

Fig. 6 The effect of time dependency of shear stress on the viability of Chaetoceros muelleri. Error bars represent 95\% confidence intervals shear stress did not reduce the viability any further. The viability was found to vary between 65 and $75 \%$ for all exposure times longer than 8 min (Fig. 6). This would suggest that the effect of shear stress is almost timeindependent. Compared to normal cultivation times, the effect can be considered as almost instantaneous. The fact that the viability does not decrease completely indicates that only the more sensitive cells are susceptible to shear stress, while the more resistant cells are not affected by shear stress even over a longer period. This result is in contrast with a study done with hybridoma cells [39]. The viability of these mammalian cells, which were also sheared for time periods of less than $2 \mathrm{~h}$, decreased over time. However, the shear stress levels applied were much higher and varied between 5 and $100 \mathrm{~Pa}$. The time dependence of shear stress was also investigated with plant cells [40]. Although the main conclusion was that the effect of shear stress on plant cells was time dependent, it was clear that the first minutes of exposure to a certain shear stress were the most detrimental. The study of Dunlop et al. [40] also showed that similar shear stress levels and exposure times as in this study gave almost the same viability results. Complete cell death was only reached when significantly higher shear stresses (50-100 Pa) were applied to the cells. These high shear stress values are expected to be unrealistic in PBRs given the low viscosity of the medium used.

\section{Conclusions}

Shear stress had an adverse effect on the viability of Chaetoceros muelleri with a threshold value between 1 and 1.3 Pa. Shear stress higher than the threshold value caused a sudden decrease in viability to levels between 52 and $66 \%$. It appears that only a certain fraction of the cells are susceptible to shear stress up to $19.4 \mathrm{~Pa}$.

No external damage was observed, meaning that internal damage must have taken place in the affected cells.

The effect of shear stress was almost instantaneous as compared to regular cultivation times. The detrimental effect already took place after $1 \mathrm{~min}$ of exposure to shear stress. The viability did not decrease any further with shear stress exposure times longer than $8 \mathrm{~min}$. This would suggest that the sensitive cells were affected by shear stress instantaneously and that high shear stress over a long period did not have a negative effect on the more resistant cells.

Acknowledgments This research is supported by the Zeeuwse Tong project (Zeeland Sole project), co-funded by the European Fisheries Fund. Furthermore, the authors thank Lieke van Riemsdijk for all her effort in the development of the shear cylinders and Katarzyna Grabowska for her assistance. 
Open Access This article is distributed under the terms of the Creative Commons Attribution Noncommercial License which permits any noncommercial use, distribution, and reproduction in any medium, provided the original author(s) and source are credited.

\section{References}

1. Spolaore P, Joannis-Cassan C, Duran E, Isambert A (2006) Commercial applications of microalgae. J Biosci Bioeng 101:87-96

2. Pulz O, Gross W (2004) Valuable products from biotechnology of microalgae. Appl Microbiol Biotechnol 65:635-648

3. Muller-Feuga A (2004) Microalgae for aquaculture. The current global situation and future trends. In: Richmond A (ed) Handbook of microalgal culture: biotechnology and applied phycology. Blackwell Science, Oxford, pp 352-364

4. Borowitzka MA (1997) Microalgae for aquaculture: opportunities and constraints. J Appl Phycol 9:393-401

5. Ugwu CU, Aoyagi H, Uchiyama H (2008) Photobioreactors for mass cultivation of algae. Bioresour Technol 99:4021-4028

6. Xu L, Weathers PJ, Xiong XR, Liu CZ (2009) Microalgal bioreactors: challenges and opportunities. Eng Life Sci 9:178-189

7. Pulz O (2001) Photobioreactors: production systems for phototrophic microorganisms. Appl Microbiol Biotechnol 57:287-293

8. Richmond A (2000) Microalgal biotechnology at the turn of the millennium: a personal view. J Appl Phycol 12:441-451

9. Lebeau T, Robert JM (2003) Diatom cultivation and biotechnologically relevant products. Part I: Cultivation at various scales. Appl Microbiol Biotechnol 60:612-623

10. Barbosa MJ, Hadiyanto, Wijffels RH (2004) Overcoming shear stress of microalgae cultures in sparged photobioreactors. Biotechnol Bioeng 85:78-85

11. Barbosa MJ, Albrecht M, Wijffels RH (2003) Hydrodynamic stress and lethal events in sparged microalgae cultures. Biotechnol Bioeng 83:112-120

12. Alías CB, García-Malea López MC, Acién Fernández FG, Fernández Sevilla JM, García Sánchez JL, Molina Grima E (2004) Influence of power supply in the feasibility of Phaeodactylum tricornutum cultures. Biotechnol Bioeng 87:723-733

13. Sánchez Mirón A, Cerón García MC, Contreras Gómez A, García Camacho F, Molina Grima E, Chisti Y (2003) Shear stress tolerance and biochemical characterization of Phaeodactylum tricornutum in quasi steady-state continuous culture in outdoor photobioreactors. Biochem Eng J 16:287-297

14. Suzuki T, Matsuo T, Ohtaguchi K, Koide K (1995) Gas-sparged bioreactors for $\mathrm{CO}_{2}$ fixation by Dunaliella tertiolecta. J Chem Technol Biotechnol 62:351-358

15. Jaouen P, Vandanjon L, Quéméneur F (1999) Stress of microalgal cell suspensions (Tetraselmis suecica) in tangential flow filtration systems: the role of pumps. Bioresour Technol 68:149-154

16. Vandanjon L, Rossignol N, Jaouen P, Robert JM, Quéméneur F (1999) Effects of shear on two microalgae species. Contribution of pumps and valves in tangential flow filtration systems. Biotechnol Bioeng 63:1-9

17. Contreras A, García F, Molina E, Merchuk JC (1998) Interaction between $\mathrm{CO} 2$-mass transfer, light availability, and hydrodynamic stress in the growth of Phaeodactylum tricornutum in a concentric tube airlift photobioreactor. Biotechnol Bioeng 60:317-325

18. García Camacho F, Gallardo Rodríguez JJ, Sánchez Mirón A, Cerón García MC, Belarbi EH, Molina Grima E (2007) Determination of shear stress thresholds in toxic dinoflagellates cultured in shaken flasks. Implications in bioprocess engineering. Process Biochem 42:1506-1515
19. Mitsuhashi S, Hosaka K, Tomonaga E, Muramatsu H, Tanishita K (1995) Effects of shear flow on photosynthesis in a dilute suspension of microalgae. Appl Microbiol Biotechnol 42:744-749

20. Moisander PH, Hench JL, Kononen K, Paerl HW (2002) Smallscale shear effects on heterocystous cyanobacteria. Limnol Oceanogr 47:108-119

21. Cussatlegras AS, Le Gal P (2005) Dinoflagellate bioluminescence in response to mechanical stimuli in water flows. Nonlinear Process Geophys 12:337-343

22. Cussatlegras AS, Le Gal P (2007) Variability in the bioluminescence response of the dinoflagellate Pyrocystis lunula. J Exp Mar Biol Ecol 343:74-81

23. Latz MI, Case JF, Gran RL (1994) Excitation of bioluminescence by laminar fluid shear associated with simple Couette flow. Limnol Oceanogr 39:1424-1439

24. Maldonado EM, Latz MI (2007) Shear-stress dependence of dinoflagellate bioluminescence. Biol Bull 212:242-249

25. Laing I (1991) Cultivation of marine unicellular algae. MAFF Laboratory Leaflet Number 67:31

26. Mezger TG (2006) The rheology handbook. Vincentz Network, Hannover

27. Bird RB, Stewart WE, Lightfoot EN (2002) Transport phenomena. Wiley, New York

28. Carreau PJ, De Kee DCR, Chabra RP (1997) Rheology of polymeric systems: principles and applications. Hanser Gardner Publications, Munich

29. O'Connor KC, Cowger NL, De Kee DCR, Schwarz RP (2002) Prolonged shearing of insect cells in a couette bioreactor. Enzyme Microb Technol 31:600-608

30. Rotman B, Papermaster BW (1966) Membrane properties of living mammalian cells as studied by enzymatic hydrolysis of fluorogenic esters. Proc Natl Acad Sci USA 55:134-141

31. Altman SA, Renders L, Rao G (1993) Comparison of trypan blue dye exclusion and fluorometric assays for mammalian cell viability determinations. Biotechnol Prog 9:671-674

32. Sipkema D, Snijders APL, Schroën CGPH, Osinga R, Wijffels RH (2004) The life and death of sponge cells. Biotechnol Bioeng 85:239-247

33. Hondzo MM, Kapur A, Lembi CA (1997) The effect of smallscale fluid motion on the green alga Scenedesmus quadricauda. Hydrobiologia 364:225-235

34. Warnaars TA, Hondzo M (2006) Small-scale fluid motion mediates growth and nutrient uptake of Selenastrum capricornutum. Freshw Biol 51:999-1015

35. Stoecker DK, Long A, Suttles SE, Sanford LP (2006) Effect of small-scale shear on grazing and growth of the dinoflagellate Pfiesteria piscicida. Harmful Algae 5:407-418

36. Van Der Veen ME, Van Iersel DG, Van Der Goot AJ, Boom RM (2004) Shear-induced inactivation of $\alpha$-amylase in a plain shear field. Biotechnol Prog 20:1140-1145

37. Van Den Einde RM, Akkermans C, Van Der Goot AJ, Boom RM (2004) Molecular breakdown of corn starch by thermal and mechanical effects. Carbohydr Polym 56:415-422

38. Van Den Einde RM, Bolsius A, Van Soest JJG, Janssen LPBM, Van Der Goot AJ, Boom RM (2004) The effect of thermomechanical treatment on starch breakdown and the consequences for process design. Carbohydr Polym 55:57-63

39. Abu-Reesh I, Kargi F (1989) Biological responses of hybridoma cells to defined hydrodynamic shear stress. J Biotechnol 9:167-178

40. Dunlop EH, Namdev PK, Rosenberg MZ (1994) Effect of fluid shear forces on plant cell suspensions. Chem Eng Sci 49(14): 2263-2276 